\title{
Mind the gap: A process model for diagnosing barriers to key account management implementation
}

\begin{abstract}
Today, many firms develop and implement key account management (KAM) programs to manage the relationships with strategically important customers. The implementation of KAM programs requires the configuration of special activities, actors, and resources dedicated to key accounts, which poses major challenges for managerial practice. Firms often underestimate the fundamental organizational change required for a successful implementation of KAM. The objective of this article is to advance extant knowledge on KAM by developing a framework that outlines essential processes to assess and diagnose barriers to KAM implementation. In our article, we integrate extant knowledge on KAM organization and enactment, and we propose a four-step process model that links the concepts of embeddedness, differentiation, integration, and alignment. In addition, we illustrate our model in a case study analysis with a large-scale European industrial company. The findings of our study allow us to derive avenues for further research on KAM implementation as well as implications for management practice.
\end{abstract}

Keywords: Differentiation; Effectiveness; Implementation; Integration; Key account management 


\section{Introduction}

Key account management (KAM) has become an important means for firms to create competitive advantage and has received strong interest in both management practice and academic research. Today, businesses in a wide range of industries develop and implement programs to manage strategically important customers and the relationships with these key accounts (KAs) (Håkansson \& Snehota, 1995; Ivens, Pardo, \& Tunisini, 2009). With KAM, firms transfer the principles of relationship marketing to customer management: firms identify KAs in the existing customer portfolio, analyze them, and they develop strategies and operational capabilities to address the demands of the KAs and build long-term cooperative relationships with them (Ivens \& Pardo, 2007; Ojasalo, 2001; Ryals \& Humphries, 2007). As such, KAM requires particular actors, activities, resources, and formalization to create value in KA relationships and appropriate value from these relationships (Homburg, Workman, \& Jensen, 2002; Workman, Homburg, \& Jensen, 2003).

Yet, the implementation of KAM in firms poses major challenges, with many firms struggling or even failing to achieve performance goals (Ryals, 2012). One important reason for this problem is that firms often underestimate the fundamental organizational change that comes with KAM. Implementing KAM requires the development of routines that extend beyond pure selling. It usually involves the creation of a dedicated function or unit that may differentiate from other units within the firm, but whose activities require internal alignment to become effective (Guesalaga \& Johnston, 2010; Pardo, Ivens, \& Wilson, 2013; 2014). A recent study shows that KAM comprises the management of relationships with actors beyond a firm's boundaries, most notably KAs, as well as the management of relationships with actors inside the supplier firm (Ivens, Pardo, Niersbach, \& Leischnig, 2016), thus underscoring the coordination tasks 
performed by KA managers and the need for integration of activities performed by KAM and internal network partners.

While research on KAM has produced a rich body of work to deepen the understanding of factors and mechanisms supporting KAM effectiveness, only a small proportion of this work has focused on KAM's organizational design (e.g., Homburg et al., 2002; Kempeners \& van der Hart, 1999) and aspects of organizational differentiation and integration (e.g., Pardo et al., 2013; 2014). Against this background, the primary objective of this research is to advance the knowledge on KAM implementation by proposing a framework that outlines essential processes to diagnose and evaluate so-called integration gaps and thus barriers to KAM implementation.

To achieve this goal, we integrate prior work on KAM organization and implementation. We theoretically ground our framework using the concepts of embeddedness (Uzzi, 1996), differentiation and integration (Lawrence \& Lorsch, 1967a, b), and frame alignment (Goffman, 1974; Snow, Rochford, Worden, \& Benford, 1986). In addition, we present the results of a case study involving 35 in-depth interviews conducted with members of two KAM units and these KAM units' firm-internal network partners of the German branch of a large-scale European industrial company.

The results of our research contribute to the KAM literature by developing an integrative perspective that connects aspects of organizational design with implementation issues. Our study provides vision for essential steps to identify and assess integration gaps. We show that integration gaps can act as barriers to KAM implementation as they interfere with inter-unit collaboration and the management of relationships with KAs. From a managerial point of view, such knowledge provides guidelines for firms to evaluate existing organizational designs, 
diagnose potential barriers to KAM implementation, and develop countermeasures to reduce or eliminate them.

We organize the remainder of this article as follows. The next section outlines the conceptual background of this study with an emphasis on KAM, the concepts of embeddedness, differentiation, alignment, and integration. We then discuss the case study and we show the results of the case study analysis. We conclude with a discussion of theoretical contributions, managerial implications, and avenues for further research.

\section{Conceptual background}

\subsection{Perspectives}

KAM is the "performance of additional activities and/or designation of special personnel directed at an organization's most important customers" (Workman et al., 2003). As such, KAM refers to a subset of a supplier firm's customer portfolio - the important customers. These customers are not simply "major customers" or "large accounts" but include customers that can have actual impact on a firm's strategy (Piercy \& Lane, 2006; Pardo, 1999), for example due to their lead user status, reputation, or market access (Ivens \& Pardo, 2007; Pardo, 1997). In managing the relationships with strategically important customers, firms perform special activities (in areas such as products, services, pricing, distribution, promotion, and information sharing) that are not offered to average customers, and they frequently assign special actors (i.e., KA managers) or build entire units (i.e., KAM units) who are dedicated to KAs (Homburg et al., 2002; Workman et al., 2003).

The motives of supplier firms to take these efforts and implement KAM are manifold and include such factors as enhancing customer orientation, keeping up with KAs' market activities, 
improving internal operations and decision-making processes, and increasing sales and sales productivity (e.g., McDonald, Millman, \& Rogers, 1997; Wengler, Ehret, \& Saab, 2006). Yet, the transition from traditional sales to KAM is challenging: it involves a long-term, multi-stage process (Davies \& Ryals, 2009) and it requires changes of organizational structures and procedures in supplier firms (Guenzi \& Storbacka, 2015). As Homburg et al. (2000, p. 463) emphasize, "[o]ne of the more significant organizational changes identified in our field research is an increasing emphasis on key account management and the establishment of customer segment managers within the sales organization." Thus, the decision to implement KAM is a strategic and fundamental one that can eventually lead to strong and profitable relationships with KAs, but that can also produce tensions and dilemmas, both on strategic as well as operational levels, within the supplier firm (Marcos-Cuevas, Nätti, Palo, \& Ryals, 2014).

Against this background, prior work highlights the need for research that contributes to the understanding of KAM's internal alignment to realize strategic fit and coordination of efforts across the organization (Guesalaga \& Johnston, 2010). Our study takes a step in this direction by examining KAM's organizational embeddedness within a supplier firm and its relationships with partners in the firm-internal network to identify integration gaps that may function as barriers to KAM implementation. Fig. 1 depicts the conceptual framework of this study. The framework is a process model encompassing four major steps: (1) the analysis of KAM's embeddedness within the firm, (2) the analysis of the level of differentiation of KAM unit(s) in comparison with other (related) units in the firm, (3) the analysis of frame alignment practices as performed by KAM units and other (related) units within the firm, and (4) the analysis of integration gaps. In what follows, we explain and discuss each of these steps in greater detail. 
Insert Fig. 1 about here.

\subsection{Embeddedness of KAM within the firm}

Based on the premise that KAM is an element of a firm-internal network (Ivens et al., 2016), the analysis of its embeddedness within the firm constitutes an important step to eventually detect integration gaps. The concept of embeddedness has its roots in the social capital and network literatures (e.g., Moran, 2005; Uzzi, 1996) and concerns the properties of a network of relations. Embeddedness has been referred to as the "impersonal configuration of linkages between people or units," thus describing the pattern of connections among multiple actors (Nahapiet \& Ghoshal, 1998, p. 244). To examine KAM’s embeddedness within a firm, three questions are of special interest: How is KAM organized in a firm? What connections exist between KAM (units) and other units within the firm? How can these connections be characterized in terms of resource flows and requisite integration?

Studies on the organizational design of KAM show that firms employ a variety of arrangements when they implement KAM (e.g., Homburg et al., 2000; Kempeners \& van der Hart, 1999; Shapiro \& Moriarty, 1984). Shapiro and Moriarty (1984) were among the first to describe KAM arrangements or programs. They distuingish between five major types of arrangements ranging from no KAM program (i.e., a situation in which firms do not form an explicit KAM system or unit) to KAM division (i.e., a situation in which firms form separate, fully integrated units to address the demands of KAs). Based upon the fundamental decision of whether or not to build a KAM unit, firms need to decide whether they position KAM as an integrated or a separated unit in the firm, and (for integrated KAM) they need to decide on the 
level of organizational positioning of KAM in the firm (i.e., business unit, division, or corporate KAM) (Kempeners \& van der Hart, 1999).

Considering additional factors related to the organizational design of KAM, Homburg et al. (2002) derive seven configurations of approaches to KAM, including such arrangements as no KAM, isolated KAM, unstructured KAM, or cross-functional, dominant KAM among others. Analysis of the performance implications of these KAM arrangements reveals that no KAM and isolated KAM perform worst, both in terms of KAM effectiveness and the accomplishment of overall firm goals. This finding suggests that firms can benefit from managing their KAs on the one hand, but that mediocre approaches to KAM with limited access to cross-functional resources can reduce the success of KAM on the other hand (Homburg et al., 2002).

It follows from this that the connections of KAM to other units in the firm have crucial roles and warrant analysis. Empirical research on these connections, however, is scarce (Workman et al., 2003). Existing studies show that one of the central challenges for KAM is to marshal resources from other units within the organization to leverage KAM capabilities (Ivens et al., 2016). KA managers need to ensure and coordinate resource flows in the firm-internal network, which typically include asset flows (e.g., organizational skills and equipment), information flows (e.g., data and knowledge), and status flows (e.g., power and commitment) (Gnyawali \& Madhavan, 2001). For example for KAM, special contractual arrangements as requested by a strategically important customer may require support and inputs from the firm's legal department. Thus, internal collaboration between KAM and its firm-internal network partners constitutes an essential prerequisite to create value for KAs and to capture value from strong and long-term KA relationships. This notion resembles the idea of requisite integration as mentioned in early work on organization (March \& Simons, 1958). 


\subsection{Differentiation of KAM}

Besides the analysis of KAM's embeddedness, our framework includes also the analysis of KAM's level of differentiation as a further relevant step to detect barriers to successful KAM implementation. Differentiation is a concept central to organizing and refers to the segmentation of an organizational system into subsystems that develop particular attributes (i.e., behaviors and orientations) (Lawrence \& Lorsch, 1967a). Prior research has shown that organizational differentiation is influenced by several factors such as environmental demands, organizational growth, strategic choices, and resource dependency (e.g., Blau 1970; Child, 1997; Lawrence \& Lorsch, 1967a, b; Pfeffer \& Salancik, 1978). By means of differentiation, firms create organizational structures consisting of units that specialize to perform specific tasks. These units, however, must also be interwoven, or integrated, in order to achieve unity of effort in the accomplishment of tasks (Lawrence \& Lorsch, 1967a). Hence, differentiation and integration are understood as antagonistic (Lawrence \& Lorsch, 1967a, b).

KAM includes the development and execution of strategies directed at one or few strategically important customers of a firm. It therefore distinguishes from other units of a firm that are organized based on other reference systems (e.g., average customers, products, processes, or projects) (Pardo et al., 2014). To understand how KAM differentiates from its network partners within the firm, prior work points to the analysis of a set of dimensions rooted in the work by Lawrence and Lorsch (1967a, b). Specifically, Pardo et al. $(2013,2014)$ suggest that (1) the degree of formalized structure, (2) orientation toward others, (3) time orientation, (4) goal orientation, (5) linguistic or semantic orientation, and (6) motivational orientation warrant consideration to study KAM's level of differentiation. 
The degree of structural formalization refers to the extent to which behavioral aspects of a firm are subject to pre-existing programs and control (Lawrence \& Lorsch, 1967a, b).

Formalization can be viewed as an impersonal coordination mode encompassing such aspects as the definition of reporting lines and formal expense budgets, the development of formal guidelines for how to perform tasks, and the documentation of processes (Boles, Pilling, \& Goodwyn, 1994; Homburg et al., 2002). While some units in a firm may show high formalization, others may be less formalized and may show greater flexibility. Orientation toward others refers to the extent to which the orientation toward the objects of work is focused on people or non-human entities (Lawrence \& Lorsch, 1967a, b). Orientation toward others manifests in specific interpersonal styles, which can be more socially oriented or more task oriented. A further dimension to assess a unit's level of differentiation from other units is time orientation. This attribute refers to reactions to the timespan of feedback. Members of a unit may be more short-term oriented (e.g., when feedback on efforts is received immediately or on short notice) or more long-term oriented (e.g., when feedback on efforts is received after a certain period of time has expired). Besides time orientation, units in a firm can differ in terms of their goal orientation, which refers to the targets at which members direct their activities. Goal orientation manifests in what persons are concerned with, which can vary considerably between organizational units (e.g., customers, competitors, products, processes, projects, etc.). Prior research shows that goal differences can interfere with inter-unit collaboration and produce conflicts (e.g., Shaw, Shaw, \& Enke, 2003). The units in a firm can be further differentiated based on their linguistic or semantic orientation. This dimension refers to "the specialized languages that develop around certain tasks and environments" (Lawrence \& Lorsch, 1967a, p. 10). For example, members of particular units in a firm may develop familiar quotations to 
describe complex issues of daily work. While such expressions may serve as shortcuts that facilitate intra-unit communication, they may be detrimental to inter-unit communication, because outgroup members may have difficulties in capturing the intended meaning of these expressions fully and correctly. Finally, a unit's level of differentiation may increase through differences in its motivational orientation compared with other units in a firm. Motivational orientation refers to the value that members of a unit derive, including such aspects as achievement, power, or social reward (Lawrence \& Lorsch, 1967a, b).

In summary, the results of step two of the analysis would improve the knowledge on how KAM unit(s) differentiate from firm-internal network partners (as identified in step one) on key dimensions. This knowledge about KAM's level of differentiation may then be used to derive integration requirements to accomplish effective collaboration and orchestrated efforts of actors in the firm-internal network. As the level of differentiation between subsystems increases, the more difficulties can arise in achieving collective action and effectiveness of integration. One critical issue within this context refers to the manifestation of differences in orientations, mental processes, attitudes, working styles, and behaviors among members in different orgenizational units (Lawrence \& Lorsch, 1969). As prior research on thought worlds indicates, such differences can have significant negative effects on the quality of inter-unit collaboration (e.g., Homburg \& Jensen, 2007).

\subsection{Internal alignment of $K A M$}

Once firms have a clear understanding of KAM's embeddedness and its level of differentiation from internal network partners, a further step involves the analysis of integrative devices used to accomplish effective collaboration with members of the internal network 
(Fig. 1). Prior work points to several integrative devices to reduce the tensions arising from differentiation. Lawrence and Lorsch (1967b) note that management hierarchy, direct inter-unit contact, control systems (rewards/punishments), inter-unit committees and task forces, and integrative units may contribute to the integration of units. In addition, Mintzberg (1989) proposes six coordinating mechanisms (i.e., mutual adjustment, direct supervision, standardization of work processes, standardization of outputs, standardization of skills, and standardization of norms) to foster inter-unit coordination. However, several of these devises are difficult to adapt to the KAM context. For instance, mechanisms based on standardization are at odds with the notion of individual customer treatment. KAM typically deals with customized solutions that require specific resource configurations, adaptiveness, and flexibility to address the demands of KAs.

In respect of these issues, the KAM literature suggests alternative approaches. For example, Guesalaga and Johnston (2010) emphasize meetings, the development of specific skills and capabilities, the shaping of specific management systems and processes, and the implementation of a matrix organization. In addition, Storbacka (2012) discusses four interorganizational alignment design elements (i.e., account portfolio definition, account business planning, account-specific value proposition, and account management process) and four intraorganizational design elements (i.e., organizational integration, support capabilities, account performance management, account team profile and skills). More recently, and drawing from theoretical frameworks developed by Goffman (1974) and Snow et al. (1986), Pardo et al. (2013; 2014) suggest frame alignment to assess the internal alignment of KAM. In line with these authors, we focus on frame alignment processes to assess the level of internal alignment. 
According to Goffman (1974, p. 21), frames denote "schemata of interpretation" that allow social entities "to locate, perceive, identify, and label" events. Frames help to render events and occurrences meaningful (Benford \& Snow, 2000) and they serve interpretive functions by enabling sensemaking and sensegiving (Gioia \& Chittipeddi, 1991). It is well established in the literature that the notions of customer focus and relationship orientation constitute the frame that guides the actions of KAM units and their members (e.g., Pardo et al. 2013; 2014). This thought world, however, may differ from those held by other units within the firm, thus representing a cause of ineffectiveness of inter-unit collaboration (e.g., Homburg \& Jensen, 2007), and underscoring the need for integrative efforts.

Frame alignment refers to the linkage of interests and interpretive frameworks held by social entities (Snow et al. 1986). Frame alignment involves efforts that aim at achieving congruence and complementarity and a shared account. Four frame alignment process have been identified in the literature: frame bridging, frame amplification, frame extension, and frame transformation. Frame bridging refers to "the linkage of two or more ideologically congruent but structurally unconnected frames regarding a particular issue or problem" (Snow et al., 1986, p. 467). Frame bridging involves alignment through dissemination of relevant information across units in the firm. For example, KAM units may manage the gathering of information about KAs and forward this information to sales units or logistics departments to ensure an effective management of the relationship with KAs. Frame amplification refers to the clarification and invigoration of interpretive frames and involves value amplification and belief amplification (Snow et al., 1986). Value amplification encompasses the "identification, idealization, and elevation of one or more values" and belief amplification involves efforts to magnify, enhance, or embellish views on entities or phenomena (Snow et al., 1986, p. 469). Such processes may 
occur when, for example, the principles of customer focus and relationship marketing are proactively promoted and endorsed by members of KAM units in the internal network. Frame extension means "extending the boundaries of $[\ldots]$ the framework so as to encompass interests or points of view that are incidental to its primary objectives but of salience to potential adherents" (Snow et al., 1986, p. 472). This notion is reflected in Shapiro and Moriarty's (1984, p. 23) statement that KA managers "work to get the managers of support functions actively involved in accounts so that they can understand, and more importantly feel their importance for the account." Finally, frame transformation refers to the redefinition or systematic alteration of existing domain-specific or global interpretive frames (Snow et al., 1986). For example, the implementation of KAM may initiate a shift in perspective away from transaction orientation to relationship orientation, thus changing preexisting frameworks that guide business conduct and operations in units of a firm.

In summary, the results of the analysis of step three of our framework improve the knowledge about the existing repertoire of frame alignment practices as performed by KAM and its internal network partners. Such knowledge is useful to improve the understanding of the extant level of integration efforts taken.

\subsection{KAM integration gaps and barriers to KAM effectiveness}

As Fig. 1 shows, the final step involves the analysis of integration gaps. Based on the results of the analyses of KAM's embeddedness within the firm, its level of differentiation in comparison with internal network partners, and the existence of frame alignment practices as performed by KAM on the one hand and internal network partners on the other hand, firms may develop an understanding of the extent to which unity of efforts (Lawrence \& Lorsch, 1967a) has 
been achieved. The higher the level of differentiation of KAM compared with its internal network partners, the more alignment practices are likely needed to ensure sufficient collaboration, seamless interaction, and orchestrated KAM activities. The final step in our model thus includes a combined analysis of differentiation and frame alignment practices.

The result of this step of the analysis may point to integration gaps, that is, conditions in which the integration efforts taken do not compensate for the integration requirements that arise from inter-unit differences and environmental demands. Integration gaps may thus function as barriers to KAM implementation, because organizational units (i.e., KAM units and their internal network partners in firms) whose collective actions influence KAM effectiveness operate in a partially aligned, unaligned, or even misaligned way, due to partially shared, decoupled, or conflicting interpretive frameworks that guide their actions. As such, integration gaps have direct implications for the intraorganizational collaboration of units and derived effects for the interorganizational relationships with KAs.

From an intraorganizational perspective, integration gaps can express in a low quality of the relationships among KAM units and their internal network partners (e.g., low levels of trust, high levels of scepticism, and conflict). In addition, they may express in inefficient inter-unit resource flows (e.g., disrupted information flows and symbolic rather than substantive actions). Once these effects externalize, the relationships with KAs may suffer (e.g., due to incorrect billing, delayed delivery, or inconsistent communication with KAs).

As prior research shows, one of the major challenges for KAM implementation is "to keep everybody on the same page" (Gueselaga \& Johnson, 2010, p. 1067). Integration gaps may point to situations in which this state may be difficult to achieve. The framework develop here provides guidelines for a systematic analysis and diagnosis of integration gaps. The following 
sections present an illustrative case study in which the above explained framework has been employed to assess KAM implementation.

\section{Case study}

\subsection{Research approach}

Case studies have been repeatedly used in prior KAM research to deepen the understanding about key actors, activities, and mechanisms in KAM (e.g., Ivens et al., 2016; Pardo et al., 2014; Ryals, 2005). The case study approach provides opportunities for understanding a given phenomenon in depth (Easton, 2010) and it leaves room for revision and adjustment of deductively derived relationships between concepts.

In our study, the analyzed case was a large-scale European industrial company. We selected this case for three primary reasons. First, the firm has a multipart KAM organization, which offered interesting insights into the embeddedness of KAM. Second, KAM programs exist in the firm for a while, which facilitated the observation and analysis of established inter-unit processes and activities. Third, the firm operates in many different countries, thus reducing biases due to legal, cultural, or other contextual factors.

The focus of analysis was on two KAM units and additional KAM-surrounding support units within the firm, that is, KAM's internal network partners. These units were investigated over a period of eleven months between November 2013 and September 2014. Following Woodside and Wilson (2003, p. 497), we used data triangulated to obtain a "deep understanding of the actors, interactions, sentiments, and behaviors occurring for a specific process through time; [...] deep understanding includes knowledge of 'sense making', processes created by individuals, and system thinking, policy mapping, and systems dynamics modeling." We used 
multiple information sources including written documents, company reports, strategy papers, internal newsletters, and internal documents related to KAM. In addition, nine field studies including direct observations were conducted. These studies involved 35 in-depth interviews with the national subsidiary's CEO, two KAM directors, senior and junior KA managers, directors of KAM's internal network partners, and the assistance of KAM teams (see Appendix). During the interviews, a mixed-method approach was used, including in-depth, open questions and questions in which the interviewees were ask to rate statements. Respondents were allowed to answer the questions without time restrictions, thus encouraging them to express all relevant issues. The interviews lasted between $90 \mathrm{~min}$ and two and a half hours. We recorded all interviews and transcribed them verbatim for subsequent analysis with the MAXQDA software program.

We analyzed the data using qualitative content analysis (Kuckartz, 2014; Schreier, 2012), which has been acknowledged as a useful method for case studies (Kohlbacher, 2005). We employed a theory-guided approach and focused the analysis on the concepts of interest in this study. We developed a coding frame, applied this frame to part of the material to assess consistency and validity, and then coded and analyzed the entire material. This procedure involved an iterative process including summary, explication, and structuring to reduce complexity and filter out the main aspects of analysis.

\subsection{Findings}

\subsubsection{KAM's organizational embeddedness}

Using the framework shown in Fig. 1, we first analyzed KAM's embeddedness within the case firm. To this end, we investigated the organizational design of KAM as well as the structure 
of its firm-internal network. In addition, and to further characterize these relationships, we examined resource flows between units and requisite integration.

KAM is organized in two KAM units, with each of the units having multiple relationships to other units in the firm. KAM unit 1 is a team of nine persons. This team exists for 12 years and all of its members are senior staff. A KAM director manages this team. All members of KAM unit 1 have been with the firm for several years and have held different positions prior to becoming KA managers. KAM unit 1 is responsible for strategically important customers that belong to one specific industry. KA managers are responsible for the definition of customerspecific offerings and processes, joint development projects, and activities linked to pricing. They split their time between home office work and traveling to KAs. KAM unit 1 has links to seven internal network partners: contracting, customer service, legal issues, market access, sales, subsidiary management, and supply chain management units. The findings indicate that, overall, KAM unit 1 depends more strongly on resources provided by the internal network partners than it is the other way around. However, for some of the internal network partners, especially contracting and market access, mutual requisite integration and situations of balanced requisite integration exist.

KAM unit 2 consists of two teams (here referred to as team $2 a$ and team $2 b$ ), with team $2 b$ being subordinated to team $2 \mathrm{a}$. Thus, KAM unit 2 shows a more complex unit structure in comparison to KAM unit 1. Team 2a exists for eight years and has seven members. Of these seven members, five persons are senior staff and two persons are juniors. A KA director who has the same authority level and responsibilities as the KA director of KAM unit 1 coordinates them. Team 2a in KAM unit 2 has many commonalities with KAM unit 1 . In contrast to KAM unit 1 , however, its members manage KAs in another industry. In addition, KA managers in team 2a are 
also responsible for the negotiation of contracts and discounts, and for the management of projects in KA firms. Team $2 \mathrm{~b}$ exists for eight years in the firm as well and has nine members who are all senior staff. Team $2 \mathrm{~b}$ is responsible for the management of KA-specific projects and concepts in the same industry as team 2a. Members of team $2 \mathrm{~b}$ report to the KA director of team 2a. KAM unit 2 has links to six internal network partners: contracting, legal issues, market access, marketing, sales, and subsidiary management units. The majority of the interviewed KA managers of KAM unit 2 experience high dependence on inputs provided by these network partners, mainly in terms of financial resources. The tasks of KAM unit 2 are primarily projectbased, which explains the need for project-related budgets.

\subsubsection{KAM's level of differentiation}

In the second step, we analyzed the level of differentiation of each of the two KAM units in comparison to their internal network partners by examining the six dimensions of structural formalization, orientation toward others, time orientation, goal orientation, linguistic orientation, and motivational orientation). We followed the procedure as outlined by Pardo et al. (2013; 2014). For example, interview partners were asked about the existence of formal rules and procedures in their units and the degree of task routinization to assess structural formalization. In addition, they were asked about the relevance and frequency of interpersonal relationships and social interactions in daily work to evaluate orientation toward others, etc. Table 1 summarizes the characteristics of the two KAM units and gives exemplary statements made by the interviewees.

For KAM unit 1, the results of the analysis revealed a rather low level of structural formalization. In addition, members of this unit employ a socially oriented, interpersonal 
approach and they have a middle- to long-term time orientation. With regard to goal orientation, it became obvious that market orientation represents the primary goal in KAM unit 1, followed by techno-economic goals. In addition, and with focus on the use of special language and expressions, the results showed that although KA managers describe linguistic and semantic gaps between the KAM unit and all interviewed internal network partners, the majority does not perceive conflict potential as a result of possibly different linguistic or semantic orientations. Finally, for motivational orientation, the results showed that KA managers of KAM unit 1 are highly intrinsically motivated through recognition and valuation, the leadership style of the superior, and an efficient and characterful internal communication and cooperation. Total income appears as an important extrinsic motivation factor for all KA managers.

Regarding KAM unit 2, the results of the analysis revealed a rather low level of structural formalization as well. However, some noteworthy differences between the two KAM teams in unit 2 (i.e., team $2 \mathrm{a}$ and team $2 \mathrm{~b}$ ) exist. Specifically, while the KA managers in team 2a perceive themselves as self-sufficient in a less formalized work environment, the KA managers in team $2 b$ feel obliged to inform their head of team about any activity they perform. In both teams, routine tasks achieve a level of about 20 to $30 \%$ of all of the tasks to be performed. Exemplary routine tasks mentioned include contract management and support services for existing structures. Similar to KAM unit 1, members of KAM unit 2 follow a socially oriented interpersonal approach, even though task orientation is not disregarded. In terms of time orientation, KAM unit 2 shows a long-term orientation. The primary concern of KAM unit 2 is market orientation, followed by science and techno-economic concerns. In line with this, members of KAM unit 2 mentioned that, in their perception, the language they use is rather market-driven, which may lead to difficulties when interacting with internal network partners. Finally, and with focus on 
motivational orientations, members of KAM unit 2 reveal to be strongly motivated by the total income. Especially KA managers of team $2 \mathrm{~b}$ express a strong motivational orientation toward money. Besides, internal cooperation constitutes an important factor of intrinsic motivation, followed by recognition and leadership style.

Insert Table 1 about here.

Having assessed the attributes of the two KAM units along the six dimensions, we compared these profiles with those of the internal network partners. To this end, interviewees from KAM-related units were asked about issues of structural formalization, their orientation toward others, etc. The comparison of the profiles revealed similarities as well as differences, which allowed us to determine the levels of differentiation. We specified the level of differentiation as "very high" when a comparison of profiles between a KAM unit and an internal network partner indicated differences on all six dimensions. In addition, we specified the level of differentiation as "high" when the profiles differed on five dimensions, as "rather high" when there were differences on four dimensions, and so on. Tables 2 and 3 summarize the results of these pairwise comparisons between the KAM units 1 and 2 and their internal network partners across the differentiation dimensions.

\subsubsection{Use of frame alignment practices}

Having identified levels of differentiation for both KAM units, we then turned to an analysis of frame alignment (i.e., step three in Fig. 1). Specifically, we examined the extent to 
which frame alignment practices (i.e., frame bridging, amplification, extension, and transformation) were used.

For KAM unit 1, the results of these analyses revealed that information diffusion processes take place in various forms (e.g., meetings with members of internal network partners; contributions to internal newsletters and internal public relations events), thus pointing to substantial frame bridging efforts. However, it is worth mentioning that some internal network partners still lack a clear understanding of KAM unit 1's tasks. The reasons for this lack of knowledge are attributed to time constraints (which impede regular meetings) and a low willingness to share relevant information. In addition, although the internal network partners generally agree on the value of the marketing concept and the principles of relationship marketing, some frictions exist. For example, KA managers report that some members of the sales units they work with still refuse to accept the mission of KAM unit 1 and do not believe in the added value that the KAM unit might bring to the firm. By means of joint projects and the installation of task forces with the internal network partners, efforts of frame extension and transformation are taken that aim at close cooperation and the translation of the KAM mission. In addition, the development of new job roles that serve as connectors, or integrators of units in the firm seeks to create consensus among network partners to stimulate cooperative work conditions.

For KAM unit 2, the results indicate that information diffusion occurs across unit boundaries in different forms as well. For example, a KA manager of team $2 \mathrm{~b}$ emphasizes that one task of the team is to gather relevant data and information in any field of the business as early as possible, to systemize and summarize them, and use them to create value for the KA on the one hand and the firm on the other hand. In addition, in-house events, and joint projects conducted together with members of units of the internal network facilitated the diffusion of 
information (frame bridging). For team $2 b$, value and belief amplification represent major challenges since the main business relates to project-based tasks with no direct impact on profits. As a result, members of team $2 b$ need to clarify and justify the value of their efforts and their contributions to the business. Regarding frame extension activities, the analysis showed that a group of KA managers exists in KAM unit 2 that is exclusively responsible for projects and concepts extending beyond the boundaries of the KAM unit. Business ideas that concern the KAM unit and the internal network partners are picked up, evaluated and translated by this group in such a way that internal network members may benefit from this information. Frame transformation activities have not been identified with regard to KAM unit 2. Tables 2 and 3 below use descriptive statements for the levels of alignment as indicated by the use of frame alignment practices.

\subsubsection{Assessment of integration gaps}

Based on the results of the preceding analyses, the final step as proposed in our framework involves the analysis of integration gaps to identify barriers to KAM implementation. The basic premise underlying this analysis is that high levels of differentiation require more integrative devices, that is, high levels of internal alignment, to achieve integration among the differentiated units and to accomplish unity of efforts for KAM implementation (Pardo et al., 2013; 2014). The combined analysis of levels of differentiation and internal alignment helps assess whether such integration has been achieved and it helps diagnose and locate integration gaps that may interfere with inter-unit collaboration (shown in the last rows in Tables 2 and 3).

Insert Tables 2 and 3 about here. 
The findings indicate integration gaps for both KAM units (KAM unit 1: four gaps; KAM unit 2: three gaps). As the results revealed, the internal networks of the two KAM units differ. KAM unit 1 has links to seven network partners within the firm and thus a more comprehensive internal network, whereas KAM unit 2 has links to six network partners. While integration gaps exist with the customer sevice unit, the legal department, sales, and the supply chain management unit for KAM unit 1, they exist with the legal department and sales for KAM unit 2. Interestingly, though different in terms of unit structure (with KAM unit 2 having a more complex unit structure), industry focus (with both KAM units serving different industries), and tasks (with KAM unit 2's tasks having a stronger project focus), integration gaps exist with the legal department and the sales units for both KAM units.

While the number of integration gaps points to the extent to which differentiated units (directly or indirectly) involved in KAM implementation are aligned and have developed shared interpretive frames, the location of integration gaps provides vision for potential barriers to KAM implementation in specific inter-unit relationships. This knowledge is useful for several reasons. First, it helps evaluate whether or not the existing repertoire of integrative efforts matches the requirements that derive from organizational segmentation and differentiation, thus providing a description of the status quo of KAM organization and implementation. Second, it helps evaluate whether or not additional integrative efforts need to be taken to harmonize frames and integrate, thus providing inputs for resource planning and reconfiguration. Third, it helps locate where, that is, in which parts of the firm-internal network, additional integrative efforts are needed, thus improving the efficiency of resource allocation. 
As sanalyses of inter-unit collaboration and relationship quality show, relationships in which no integration gaps exist indicate higher relationship quality than relationships in which integration gaps exist. For example, members of KAM unit 1 characterize the relationships with contracting and market access as excellent and harmonic, whereas they judge the relationships with sales units as conflict-laden and problematic. Likewise, members of KAM unit 2 perceive the relationship with contracting and market access as positive and harmonic, whereas they perceive the relationship with the legal department and with marketing as characterized by frequent misunderstandings and competitive pressures, respectively. In summary, these findings indicate that integration gaps function to create barriers to KAM implementation, because they interfere with inter-unit collaboration and prevent concerted efforts to manage KA relationships seamlessly.

\section{Discussion}

\subsection{Theoretical contributions}

With KAM now being an integral element in many firms, the question of how to successfully implement it in daily business has become a top priority not only in business practice but also in academic research. Our article seeks to contribute to the literature on KAM, and especially KAM implementation, by proposing a framework that provides vision for barriers to KAM implemenation, here referred to as integration gaps. Based upon the notions that "no business is and island" (Håkansson \& Snehota, 1989, p. 187) and that KAM involves the management of networks with actors beyond a firm's boundaries as well as inside a firm (Ivens et al., 2016), we adopted an intraorganizational perspective and examined how the organizational 
design of KAM and the implications that derive can lead to integration gaps that may infer with KAM implementation. As such, our research makes several contributions to the literature.

First, our article proposes a process model that links key concepts of KAM organization and implementation, namely embeddedness, differentiation, alignment, and integration. Our article thus connects extant debates in the KAM literature and suggests a systemization in form of a process model that consists of four major steps. The process model helps diagnose integration gaps which can prevent KAM implementation, thus following well-established traditions in management research (Lawrence \& Lorsch, 1969, p. 85): "It is the work of analysis and diagnosis to translate the symptoms into a coherent picture on the basis of which action can be planned and carried out with a reasonable assurance that objectives will be achieved. (...) Once a reasonable complete diagnosis is developed, it in itself tends to induce the next necessary steps: specifying the desired direction of change and identifying the more promising variables which should be altered to allow the organization to move in the desired direction."

A further contribution of this research refers to the linkage of KAM's embeddedness within the firm with the concepts of differentiation and integration. Prior research on KAM implementation has most commonly focused on the latter two concepts and their relationships (e.g., Pardo et al., 2013; 2014). In our research, we show that an important preceding step is the analysis of KAM's embeddedness to develop an undestanding of the organizational design of KAM, its links to other units within the firm, and the nature of these links. The analysis of KAM's embeddedness discloses actors, relationship structures, and resource flows and, as such, provides inputs for subsequent assessments.

Related to this point, our research makes a further contribution to the KAM literature by illustrating such assessments in a case study with a large-scale industrial company. Based on an 
analysis of qualitative data from interviews with members of two KAM units and their internal network partners, as well as analyses of supplementary material, we demonstrate each of the steps as proposed in our framework. The results of the case study analysis demonstrate how to diagnose integration gaps and they clarify why the analysis of such gaps warrants consideration, which provides guidance for researchers as well as managers.

Our research reveals differences between KAM and its network partners within the firrm on several dimensions, especially in comparison with the legal department and sales. These findings mirror those of previous studies (e.g., Sergius Koku, 2007; Millman \& Wilson, 1995). For example, regarding the KAM-sales divide, Millman and Wilson (1995, p. 18) note that "[w]hile it may be argued that the origins of KAM lie in the sales function, there is mounting evidence to question whether KAM activities should be retained under sales or set up as a separate entity at general management level."

\subsection{Managerial implications}

Besides theoretical contributions, our article allows us to derive several implications for management practice. The key messages that the findings of our research suggest to managers are as follows: (1) as a per definitionem differentiated unit (Pardo et al., 2013), KAM requires

integration, which can be achieved through frame alignment practices, (2) integration gaps due to high levels of differentiation and insufficient alignment are detrimental to successful KAM implementation and thus need to be detected, (3) the process model as outlined here helps diagnose and locate integration gaps and develop countermeasures.

A first important implication that derives from the findings of this study is that top management teams should be sensitive to integration requirements, approach this topic in a 
transparent and direct manner, and provided needed resources for internal alignment (Oliva, 2006). Because internal alignment reflects the values, goal, and ideologies of top management (Barki \& Pinsonneault 2005), it is essential that the top management has confidence in and is committed to KAM. The importance of top management support in KAM has been discussed repeatedly in prior work (e.g., Homburg et al., 2002; Pardo, 1999; Zupancic, 2008). Yet, it remains to be investigated how top managers engage in aligning KAM units internally (Pardo et al., 2013). Besides, the leadership style of KA directors who encourage and account for interunitl coordination and communication appears to be key in the alignment process. A KAM unit leader is thought to be a senior manager who "(a) is structurally a part of an involved firm's top management, (b) has authority to make marketing decisions across firm boundaries, and (c) has the capability and capacity to operate throughout the internal-external network" (Hult, 2011, p. 527). KAM units which emphasize cohesiveness, participation and teamwork are more effective and competitive in the long-run and thus able to act more quickly in a given environment (Hult, 2011). Hence, for internal alignment, 'esprit de corps' becomes essential when goal conflicts between KAM units and internal network partner occur, which may be influenced by leadership styles.

A further implication that the findings of our study have refers to integration gaps that may occur because insufficient internal alignement cannot bridge inter-unit differentiation. The reasons for such insufficiencies are manifold and can include such issues as a cultural, structural, or resource-related obstacles. Hence, and to ensure sufficient alignment, firms need to establish a culture based on integrative frames that allow identification and internalization. In addition, constraints of daily work that might interfere with internal alignments (e.g., time constraints) should be reduced or even eliminated, for example through new models of work design. 
Moreover, alignment practices require resources (personnel, money, technology, etc.) to bring activities alive and enhance internal cohesion and collaboration. These resources should be considered in firm-internal resource management programs.

Finally, the presence of integration gaps may lead to adaption and reconfiguration of existing alignment practices. While such adaptations may improve the integration of KAM in the long-term, they may lead to irritations and misunderstandings among internal network partners in the short-term. Hence, firms should be aware that changes in the existing repertoire of integrative devices may be misinterpreted. To prevent and avoid such irritations, adaptations and reconfigurations of firm-internal alignment practices should be accompanied by appropriate communication programs that clarify needed changes.

\subsection{Avenues for further research}

The implementation of KAM is a long-term process with multiple stages (Davies \& Ryals, 2009). As such, the organizational design of KAM and its internal network structure is subject to change. For example, changes in the number of KA managers, the composition of KA teams, or the assignment of KA teams to KA units will likely occur as a firm matures and relationships with customers develop. Hence, further research is needed that takes a long-term perspective and that conducts longitudinal analyses to improve the understanding of how KAM's organizational embeddedness and its level of differentiation from internal network partners evolve. Such research would improve the knowledge on KAM evolution in firms and it might offer insights into causes of structural and procedural changes of KAM over time and their implications for KAM effectiveness. 
A further avenue for future studies pertains to frame alignment in the context of KAM implementation. In our research, we adopted an intraorganizational perspective and examined frame alignment among KAM units and the network partners within the firm. As prior research shows, an important prerquisite for KAM to be effective is a close match between supplier and KA relationship requirements (Piercy \& Lane, 2006). Thus, future studies may extend to interorganizational frame alignment and examine the processes of frame bridging, amplification, extension, and transformation with regard to KA managers and KAs. Such research would enhance the concept of frame alignment in KAM contexts and complement the insights on intraorganizational frame alignment practices.

Finally, future studies could consider alternative modes of internal aligment and examine their effectiveness as integrative devices. For example, Corsaro and Snehota (2011) reveal alignment of practices and alignment of goals besides cognitive alignment. Future studies might extend the framework outlined here and consider these modes of alignment as well. Specifically, future research might examine what configurations of internal aligment modes are sufficient to reduce or prevent integration gaps. Such research might use fuzzy-set Qualitative Comparative Analyses (fsQCA; Ragin, 2008), which have received increased interest in the sales and personal selling literature in recent years (e.g., Leischnig, Henneberg, \& Thornton, 2016; Leischnig, Ivens, \& Henneberg, 2015; Leischnig \& Kasper-Brauer, 2016). 


\section{References}

Barki, H., \& Pinsonneault, A. (2005). A model of organizational integration, implementation effort, and performance. Organization Science, 16(2), 165-179.

Benford, R. D., \& Snow, D. A. (2000). Framing processes and social movements: An overview and assessment. Annual Review of Sociology, 26(1), 611-639.

Blau, P. M. (1970). A formal theory of differentiation in organizations. American Sociological Review, 35(2), 201-218.

Boles, J. S., Pilling, B. K., \& Goodwyn, G. W. (1994). Revitalizing your national account marketing program: the NAM audit. Journal of Business \& Industrial Marketing, 9(1), 24 33.

Child, J. (1997). Strategic choice in the analysis of action, structure, organizations and environment: Retrospect and prospect. Organization Studies, 18(1), 43-76.

Corsaro, D., \& Snehota, I. (2011). Alignment and misalignment in business relationships. Industrial Marketing Management, 40(6), 1042-1054.

Davies, I. A., \& Ryals, L. J. (2009). A stage model for transitioning to KAM. Journal of Marketing Management, 25(9-10), 1027-1048.

Easton, G. (2010). Critical realism in case study research. Industrial Marketing Management, 39(1), 118-128.

Gioia, D. A., \& Chittipeddi, K. (1991). Sensemaking and sensegiving in strategic change initiation. Strategic Management Journal, 12(6), 433-448.

Gnyawali, D. R., \& Madhavan, R. (2001). Cooperative networks and competitive dynamics: A structural embeddedness perspective. Academy of Management Review, 26(3), 431-445. 
Goffman, E. (1974). Frame analysis: An essay on the organization of experience. Cambridge, MA: Harvard University Press.

Guenzi, P., \& Storbacka, K. (2015). The organizational implications of implementing key account management: A case-based examination. Industrial Marketing Management, 45, 84-97.

Guesalaga, R., \& Johnston, W. (2010). What's next in key account management research? Building the bridge between the academic literature and the practitioners' priorities. Industrial Marketing Management, 39(7), 1063-1068.

Håkansson, H., \& Snehota, I. (1989). No business is an island: the network concept of business strategy. Scandinavian Journal of Management, 5(3), 187-200.

Håkansson, H. \& Snehota, I., (Eds.). (1995). Developing relationships in business networks. London: Routledge.

Homburg, C., \& Jensen, O. (2007). The thought worlds of marketing and sales: which differences make a difference?. Journal of Marketing, 71(3), 124-142.

Homburg, C., Workman Jr, J. P., \& Jensen, O. (2002). A configurational perspective on key account management. Journal of Marketing, 66(2), 38-60.

Kohlbacher, F. (2006). The use of qualitative content analysis in case study research. Forum Qualitative Sozialforschung/Forum: Qualitative Social Research (Vol. 7, No. 1).

Miles, M. B., Huberman, A. M., \& Saldaña, J. (2014). Qualitative data analysis: A methods sourcebook. Thousand Oaks, CA: Sage.

Hult, G. T. M. (2011). Toward a theory of the boundary-spanning marketing organization and insights from 31 organization theories. Journal of the Academy of Marketing Science, 39(4), 509-536. 
Ivens, B. S., \& Pardo, C. (2007). Are key account relationships different? Empirical results on supplier strategies and customer reactions. Industrial Marketing Management, 36(4), 470482.

Ivens, B. S., Pardo, C., Niersbach, B., \& Leischnig, A. (2016). Firm-internal key account management networks: Framework, case study, avenues for future research. Industrial Marketing Management, 58(10), 102-113.

Ivens, B. S., Pardo, C., \& Tunisini, A. (2009). Organizing and integrating marketing and purchasing in business markets: An introduction to the special issue, issues and implications. Industrial Marketing Management, 38(8), 851-856.

Kempeners, M. A., \& van der Hart, H. W. (1999). Designing account management organizations. Journal of Business \& Industrial Marketing, 14(4), 310-335.

Kuckartz, U. (2014). Qualitative text analysis: A guide to methods, practice and using software. London, UK, et al:: Sage.

Lawrence, P. R., Garrison, J. S., \& Lorsch, J. W. (1967). Organization and environment: Managing differentiation and integration. Boston, MA: Div. of Research, Graduate School of Business Administration, Harvard University.

Lawrence, P. R., \& Lorsch, J. W. (1967a). Differentiation and integration in complex organizations. Administrative Science Quarterly, 12(1), 1-47.

Lawrence, P., \& Lorsch, J. W. (1967b). Organization and environment: Managing differentiation and integration (revised edition 1989). Boston, MA: Harvard Business School Press. 
Lawrence, P., \& Lorsch, J. W. (1969). Developing organizations. Diagnosis and action.

Addison-Wesley series on organization development. Reading, MA: Addison-Wesley Pub. Co.

Leischnig, A., Henneberg, S. C., \& Thornton, S. C. (2016). Net versus combinatory effects of firm and industry antecedents of sales growth. Journal of Business Research, 69(9), 35763583.

Leischnig, A., Ivens, B. S., \& Henneberg, S. C. (2015). When stress frustrates and when it does not: Configural models of frustrated versus mellow salespeople. Psychology \& Marketing, 32(11), 1098-1114.

Leischnig, A., \& Kasper-Brauer, K. (2016). How to sell in diverse markets? A two-level approach to industry factors and selling factors for explaining firm profitability. Journal of Business Research, 69(4), 1307-1313.

March, J. G., \& Simon, H. A. (1958). Organizations. New York: John Wiley.

Marcos-Cuevas, J., Nätti, S., Palo, T., \& Ryals, L. J. (2014). Implementing key account management: Intraorganizational practices and associated dilemmas. Industrial Marketing Management, 43(7), 1216-1224.

McDonald, M., Millman, T., \& Rogers, B. (1997). Key account management: Theory, practice and challenges. Journal of Marketing Management, 13(8), 737-757.

Millman, T., \& Wilson, K. (1995). From key account selling to key account management. Journal of Marketing Practice: Applied Marketing Science, 1(1), 9-21.

Mintzberg, H. (1989), Mintzberg on management. Inside our strange world of organizations. New York, London: Free Press; Collier Macmillan. 
Moran, P. (2005). Structural vs. relational embeddedness: social capital and managerial performance. Strategic Management Journal, 26(12), 1129-1151.

Nahapiet, J., \& Ghoshal, S. (1998). Social capital, intellectual capital, and the organizational advantage. Academy of Management Review, 23(2), 242-266.

Ojasalo, J. (2001). Key account management at company and individual levels in business-tobusiness relationships. Journal of Business \& Industrial Marketing, 16(3), 199-220.

Oliva, R. A. (2006). The three key linkages: improving the connections between marketing and sales. Journal of Business and Industrial Marketing, 21(6), 395-398.

Pardo, C. (1997). Key account management in the business to business field: The key account's point of view. Journal of Personal Selling \& Sales Management, 17(4), 17-26.

Pardo, C. (1999). Key account management in the business-to-business field: A French overview. Journal of Business \& Industrial Marketing, 14(4), 276-297.

Pardo, C., Ivens, B. S., \& Wilson, K. (2013). Assessing and strengthening internal alignment of new marketing units: an interpretative tool. Industrial Marketing Management, 42(7), 1074-1082.

Pardo, C., Ivens, B. S., \& Wilson, K. (2014). Differentiation and alignment in KAM implementation. Industrial Marketing Management, 43(7), 1136-1145.

Pfeffer, J. \& Salancik, G. R. (1978). The external control of organizations: A resource dependency perspective. New York, NY: Harper \& Row.

Piercy, N. F., \& Lane, N. (2006). The hidden risks in strategic account management strategy. Journal of Business Strategy, 27(1), 18-26.

Ragin, C. C. (2008). Redesigning social inquiry: Fuzzy sets and beyond (Vol. 240). Chicago, IL: University of Chicago Press. 
Ryals, L. (2005). Making customer relationship management work: the measurement and profitable management of customer relationships. Journal of Marketing, 69(4), 252-261.

Ryals, L. (2012). How to succeed at key account management. Harvard Business Review. Blog Network.

Ryals, L. J., \& Humphries, A. S. (2007). Managing key business-to-business relationships: What marketing can learn from supply chain management. Journal of Service Research, 9(4), $312-326$.

Schreier, M. (2012). Qualitative content analysis in practice. London, UK, et al.: Sage.

Sergius Koku, P. (2007). Turf wars or a misunderstanding of roles: An examination of the relationship between marketers and lawyers within the corporation. Journal of Services Marketing, 21(1), 15-23.

Shapiro, B. P., \& Moriarty, R. T. (1984a). Organizing the national account force. Cambridge, Massachusetts: Marketing Science Institute, Report No. 84-101.

Shaw, V., Shaw, C. T., \& Enke, M. (2003). Conflict between engineers and marketers: The experience of German engineers. Industrial Marketing Management, 32(6), 489-499.

Snow, D. A., Rochford Jr, E. B., Worden, S. K., \& Benford, R. D. (1986). Frame alignment processes, micromobilization, and movement participation. American Sociological Review, 51(4), 464-481.

Storbacka, K. (2012). Strategic account management programs: Alignment of design elements and management practices. Journal of Business \& Industrial Marketing, 27(4), 259-274.

Uzzi, B. (1996). The sources and consequences of embeddedness for the economic performance of organizations: the network effect. American Sociological Review, 61(4), 674-698. 
Wengler, S., Ehret, M., \& Saab, S. (2006). Implementation of Key Account Management: Who, why, and how? An exploratory study on the current implementation of Key Account Management programs. Industrial Marketing Management, 35(1), 103-112.

Woodside, A. G., \& Wilson, E. J. (2003). Case study research methods for theory building. Journal of Business \& Industrial Marketing, 18(6/7), 493-508.

Workman Jr, J. P., Homburg, C., \& Jensen, O. (2003). Intraorganizational determinants of key account management effectiveness. Journal of the Academy of Marketing Science, 31(1), 3-21.

Zupancic, D. (2008). Towards an integrated framework of key account management. Journal of Business \& Industrial Marketing, 23(5), 323-331. 
Fig 1. Conceptual framework

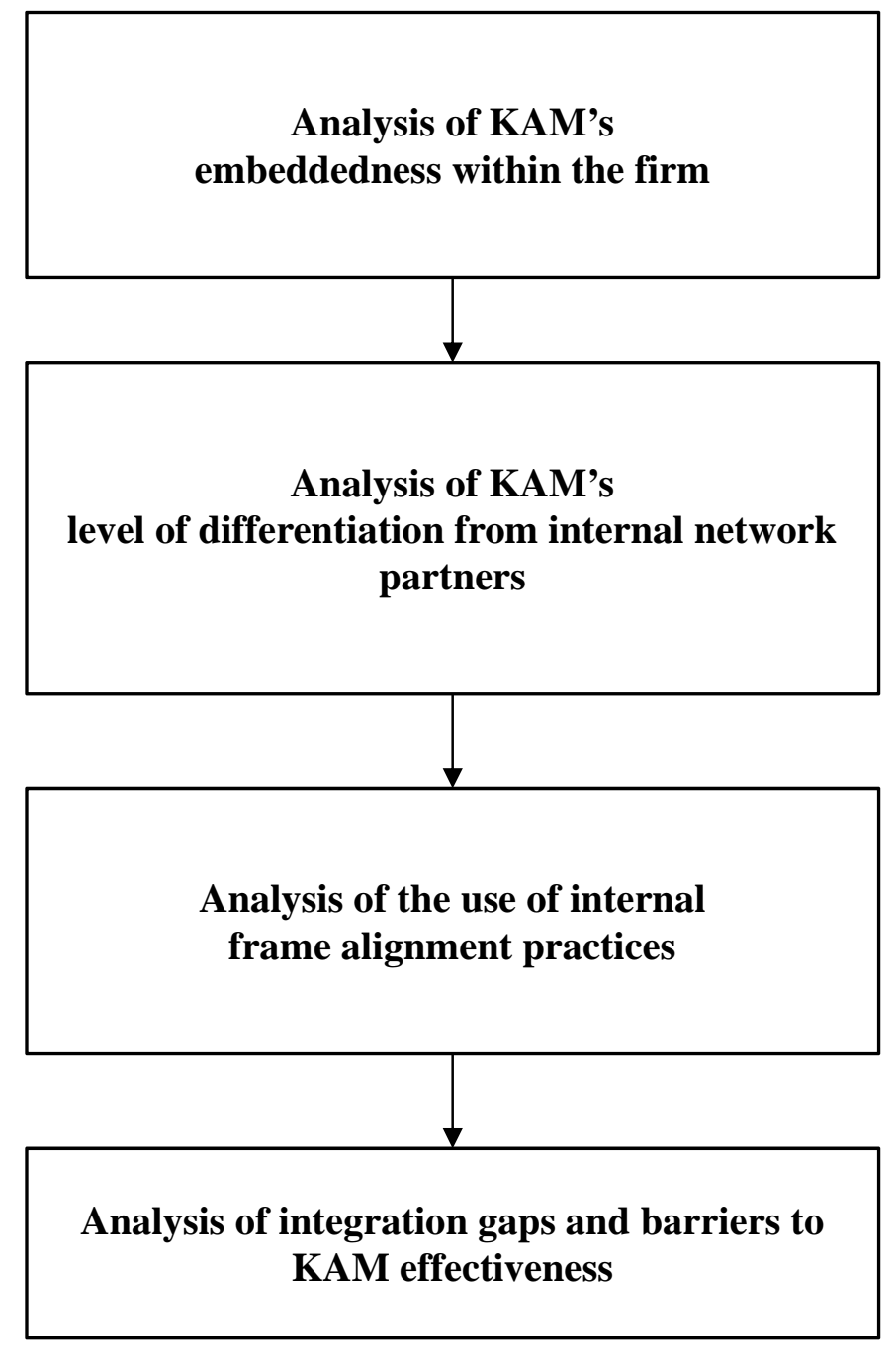

- How is KAM organized within the firm?

- What connections exist between KAM and other units within the firm?

- What is the degree of requisite integration?

- How differentiated is KAM units in comparison with partners in the internal network in terms of:

(1) structural formalization, (2) orientation toward others, (3) time orientation, (4) goal orientation, (5) linguistic orientation, and (6) motivational orientation?

- What frame alignment practices perform KAM and partners in the internal network in terms of:

(1) frame bridging, (2) frame amplification, (3) frame extension, and (4) frame transformation?

- Are there integration gaps between KAM and partners in the internal network that hinder an effective collaboration? 
Table 1

Characteristics of KAM unit 1 and KAM unit 2

\begin{tabular}{|c|c|c|c|c|c|c|c|}
\hline & & $\begin{array}{c}\text { Structural } \\
\text { formalization }\end{array}$ & $\begin{array}{l}\text { Orientation } \\
\text { toward others }\end{array}$ & $\begin{array}{c}\text { Time } \\
\text { orientation }\end{array}$ & $\begin{array}{l}\text { Goal } \\
\text { orientation }\end{array}$ & $\begin{array}{l}\text { Linguistic } \\
\text { orientation }\end{array}$ & $\begin{array}{c}\text { Motivational } \\
\text { orientation }\end{array}$ \\
\hline \multirow[t]{2}{*}{$\begin{array}{l}\text { KAM } \\
\text { unit } 1\end{array}$} & Findings & Low & Interpersonal & $\begin{array}{l}\text { Middle to long- } \\
\text { term }\end{array}$ & $\begin{array}{c}\text { 1st market } \\
\text { orientation, 2nd } \\
\text { techno-economic } \\
\text { orientation }\end{array}$ & $\begin{array}{c}\text { Use of specific } \\
\text { language }\end{array}$ & $\begin{array}{l}\text { Recognition, } \\
\text { income }\end{array}$ \\
\hline & $\begin{array}{l}\text { Exemplary } \\
\text { statements }\end{array}$ & $\begin{array}{l}\text { "Of course there } \\
\text { are a few formal } \\
\text { rules, like filling } \\
\text { out some formal } \\
\text { templates, for } \\
\text { example, but the } \\
\text { majority of rules } \\
\text { and procedures } \\
\text { are of an } \\
\text { informal nature." }\end{array}$ & $\begin{array}{l}\text { “Interpersonal } \\
\text { relationships are } \\
\text { key. It's our job } \\
\text { to get along with } \\
\text { people. For a KA } \\
\text { manager, the } \\
\text { most important } \\
\text { criterion is social } \\
\text { competence." }\end{array}$ & $\begin{array}{l}\text { "We all work } \\
\text { here on a very } \\
\text { short-term basis. } \\
\text { I consider short- } \\
\text { term to be the } \\
\text { goals within } \\
\text { weeks or months. } \\
\text { Our goals are at } \\
\text { least defined for } \\
\text { one year, one to } \\
\text { two years. This, I } \\
\text { would say, is } \\
\text { middle- and long- } \\
\text { term." }\end{array}$ & $\begin{array}{l}\text { Captured based } \\
\text { on interviewees' } \\
\text { ratings of nine } \\
\text { statements as } \\
\text { proposed by } \\
\text { Lawrence, } \\
\text { Garrison, \& } \\
\text { Lorsch (1967). }\end{array}$ & $\begin{array}{l}\text { “KAM and my } \\
\text { unit speak the } \\
\text { same language. } \\
\text { But the other } \\
\text { units don't } \\
\text { understand us. } \\
\text { For me it's a } \\
\text { challenge to have } \\
\text { to make sure that } \\
\text { the other people } \\
\text { understand what } \\
\text { you're talking } \\
\text { about.” }\end{array}$ & $\begin{array}{l}\text { Capture based on } \\
\text { interviewees' } \\
\text { ratings of } \\
\text { different } \\
\text { motivational } \\
\text { factors. }\end{array}$ \\
\hline
\end{tabular}


Table 1 continued

\begin{tabular}{|c|c|c|c|c|c|c|c|}
\hline & & $\begin{array}{c}\text { Structural } \\
\text { formalization }\end{array}$ & $\begin{array}{l}\text { Orientation } \\
\text { toward others }\end{array}$ & $\begin{array}{c}\text { Time } \\
\text { orientation }\end{array}$ & $\begin{array}{c}\text { Goal } \\
\text { orientation }\end{array}$ & $\begin{array}{l}\text { Linguistic } \\
\text { orientation }\end{array}$ & $\begin{array}{l}\text { Motivational } \\
\text { orientation }\end{array}$ \\
\hline \multirow[t]{2}{*}{$\begin{array}{l}\text { KAM } \\
\text { unit } 2\end{array}$} & Findings & Low & Interpersonal & Long-term & $\begin{array}{c}1 \text { st market } \\
\text { orientation; } 2 \text { nd } \\
\text { scientific and } \\
\text { techno-economic } \\
\text { orientation }\end{array}$ & $\begin{array}{l}\text { Use of specific } \\
\text { language }\end{array}$ & $\begin{array}{l}\text { Income, } \\
\text { cooperation }\end{array}$ \\
\hline & $\begin{array}{l}\text { Exemplary } \\
\text { statements }\end{array}$ & $\begin{array}{l}\text { "Of course there } \\
\text { are routines - } \\
\text { classical contract } \\
\text { management, } \\
\text { supervision of } \\
\text { existent projects } \\
\text { or also customers } \\
\text { for example (...). } \\
\text { However, I think } \\
\text { that our firm is } \\
\text { very flexible, } \\
\text { which I think is a } \\
\text { good thing." }\end{array}$ & $\begin{array}{l}\text { "KAM is a very } \\
\text { relationship- } \\
\text { oriented } \\
\text { business. So, a } \\
\text { lack of social } \\
\text { orientation is an } \\
\text { issue. For my job, } \\
\text { social orientation } \\
\text { is absolutely } \\
\text { necessary." }\end{array}$ & $\begin{array}{l}\text { "Middle-term for } \\
\text { me is everything } \\
\text { between two and } \\
\text { three years. } \\
\text { Long-term is } \\
\text { strategic } \\
\text { business. This } \\
\text { understanding of } \\
\text { time horizons } \\
\text { matches that of } \\
\text { our customers." }\end{array}$ & $\begin{array}{c}\text { Captured based } \\
\text { on interviewees } \\
\text { ratings of nine } \\
\text { statements as } \\
\text { proposed by } \\
\text { Lawrence, } \\
\text { Garrison, \& } \\
\text { Lorsch (1967). }\end{array}$ & $\begin{array}{l}\text { "Internally, there } \\
\text { are many } \\
\text { abbreviations, for } \\
\text { example, for } \\
\text { meetings, } \\
\text { information } \\
\text { exchange } \\
\text { platforms, and } \\
\text { department- } \\
\text { specific terms } \\
\text { that I didn't know } \\
\text { at the } \\
\text { beginning." }\end{array}$ & $\begin{array}{l}\text { Capture based on } \\
\text { interviewees' } \\
\text { ratings of } \\
\text { different } \\
\text { motivational } \\
\text { factors. }\end{array}$ \\
\hline
\end{tabular}


Table 2

KAM unit 1: embeddness, differentiation, internal alignment, and integration gaps

\begin{tabular}{|c|c|c|c|c|c|c|c|}
\hline & \multicolumn{7}{|c|}{ Internal network partner } \\
\hline & Contracting & $\begin{array}{c}\text { Customer } \\
\text { service }\end{array}$ & Legal & $\begin{array}{l}\text { Market } \\
\text { access }\end{array}$ & Sales & Subsidiary & SCM \\
\hline Structural formalization & & $\times$ & $\times$ & & $\times$ & & $\times$ \\
\hline Orientation toward others & $x$ & $x$ & $x$ & $x$ & & & $x$ \\
\hline Time orientation & $x$ & $\times$ & $\times$ & & $x$ & & $x$ \\
\hline Goal orientation & $x$ & $x$ & $x$ & $x$ & $x$ & $x$ & $x$ \\
\hline Linguistic orientation & & $x$ & $x$ & $x$ & $x$ & $x$ & $x$ \\
\hline Motivational orientation & & $\times$ & $\times$ & & $x$ & $x$ & $\times$ \\
\hline Level of differentiation ${ }^{a}$ & $\begin{array}{l}\text { rather } \\
\text { low }\end{array}$ & $\begin{array}{l}\text { very } \\
\text { high }\end{array}$ & $\begin{array}{l}\text { very } \\
\text { high }\end{array}$ & $\begin{array}{l}\text { rather } \\
\text { low }\end{array}$ & high & $\begin{array}{l}\text { rather } \\
\text { low }\end{array}$ & $\begin{array}{l}\text { very } \\
\text { high }\end{array}$ \\
\hline Level of alignment ${ }^{b}$ & $\begin{array}{l}\text { rather } \\
\text { high }\end{array}$ & $\begin{array}{c}\text { rather } \\
\text { low }\end{array}$ & $\begin{array}{c}\text { rather } \\
\text { low }\end{array}$ & $\begin{array}{l}\text { rather } \\
\text { high }\end{array}$ & $\begin{array}{l}\text { rather } \\
\text { low }\end{array}$ & $\begin{array}{l}\text { rather } \\
\text { high }\end{array}$ & $\begin{array}{c}\text { rather } \\
\text { high }\end{array}$ \\
\hline Integration gaps ${ }^{c}$ & no & yes & yes & no & yes & no & yes \\
\hline
\end{tabular}

Notes: SCM = Supply Chain Management; $\times$ indicate differentiation between KAM unit 1 and the respective internal network partner; a scale: "very low", "low", "rather low", "rather high", "high", "very high"; b scale: "low", "rather low", "rather high", "high";

" "yes" if the level of differentiation is higher than the level of alignment, "no" otherwise. 
Table 3

KAM unit 2: embeddness, differentiation, and internal alignment

\begin{tabular}{|c|c|c|c|c|c|c|}
\hline & \multicolumn{6}{|c|}{ Internal network partner } \\
\hline & Contracting & Legal & $\begin{array}{c}\text { Market } \\
\text { access }\end{array}$ & Marketing & Sales & Subsidiary \\
\hline Structural formalization & & $\times$ & & & $\times$ & \\
\hline Orientation toward others & $x$ & $x$ & $x$ & $x$ & & \\
\hline Time orientation & $x$ & $x$ & & & $x$ & $x$ \\
\hline Goal orientation & $x$ & $x$ & $x$ & $\times$ & $x$ & $x$ \\
\hline Linguistic orientation & & $x$ & $x$ & $x$ & $x$ & $x$ \\
\hline Motivational orientation & & $x$ & & $x$ & $\times$ & $x$ \\
\hline Level of differentiation ${ }^{a}$ & $\begin{array}{c}\text { rather } \\
\text { low }\end{array}$ & $\begin{array}{l}\text { very } \\
\text { high }\end{array}$ & $\begin{array}{l}\text { rather } \\
\text { low }\end{array}$ & $\begin{array}{l}\text { rather } \\
\text { high }\end{array}$ & high & $\begin{array}{l}\text { rather } \\
\text { high }\end{array}$ \\
\hline Level of alignment ${ }^{b}$ & $\begin{array}{l}\text { rather } \\
\text { high }\end{array}$ & $\begin{array}{c}\text { rather } \\
\text { low }\end{array}$ & $\begin{array}{l}\text { rather } \\
\text { high }\end{array}$ & $\begin{array}{c}\text { rather } \\
\text { low }\end{array}$ & $\begin{array}{c}\text { rather } \\
\text { low }\end{array}$ & $\begin{array}{l}\text { rather } \\
\text { high }\end{array}$ \\
\hline Integration gaps $^{c}$ & no & yes & no & yes & yes & no \\
\hline
\end{tabular}

Notes: $\times$ indicate differentiation between KAM unit 2 and the respective internal network partner; " scale: "very low", "low", "rather low", "rather high", "high", "very high"; b scale: "low", "rather low", "rather high", "high"; " "yes" if the level of differentiation is higher than the level of alignment, "no" otherwise. 


\section{Appendix}

A1: Information on interview partners

\begin{tabular}{|c|c|c|c|}
\hline $\begin{array}{l}\text { Interview } \\
\text { partner }\end{array}$ & $\begin{array}{l}\text { Organizational } \\
\text { unit }\end{array}$ & Position & $\begin{array}{l}\text { Organizational } \\
\text { tenure (years) }\end{array}$ \\
\hline I1 & Company board & $\mathrm{CEO}$ & 3 \\
\hline $\mathrm{I} 2$ & KAM unit 1 & Director & 29 \\
\hline $\mathrm{I} 3$ & KAM unit 1 & Manager & 12 \\
\hline I4 & KAM unit 1 & Manager & 10 \\
\hline $\mathrm{I} 5$ & KAM unit 1 & Manager & 22 \\
\hline I6 & KAM unit 1 & Manager & 11 \\
\hline I7 & KAM unit 1 & Manager & 22 \\
\hline I8 & KAM unit 2 & Director & 8 \\
\hline I9 & KAM unit 2 & Manager & 7 \\
\hline $\mathrm{I} 10$ & KAM unit 2 & Manager & 14 \\
\hline $\mathrm{I} 11$ & KAM unit 2 & Manager & 14 \\
\hline $\mathrm{I} 12$ & KAM unit 2 & Manager & 2 \\
\hline $\mathrm{I} 13$ & KAM unit 2 & Manager & 2 \\
\hline $\mathrm{I} 14$ & KAM unit 2 & Manager & 9 \\
\hline $\mathrm{I} 15$ & KAM unit 2 & Manager & 22 \\
\hline I16 & KAM unit 2 & Manager & 14 \\
\hline $\mathrm{I} 17$ & KAM unit 2 & Manager & 10 \\
\hline $\mathrm{I} 18$ & KAM unit 2 & Manager & 23 \\
\hline I19 & KAM unit 2 & Manager & 28 \\
\hline $\mathrm{I} 20$ & KAM units $1 \& 2$ & Assistant & 14 \\
\hline $\mathrm{I} 21$ & Contracting & Director & 20 \\
\hline $\mathrm{I} 22$ & Contracting & Employee & 6 \\
\hline $\mathrm{I} 23$ & Customer service & Head of Unit & 16 \\
\hline $\mathrm{I} 24$ & Legal & Head of Unit & 15 \\
\hline $\mathrm{I} 25$ & Legal & Employee & 2 \\
\hline $\mathrm{I} 26$ & Market access & Head of Unit & 7 \\
\hline $\mathrm{I} 27$ & Market access & Manager & 4 \\
\hline $\mathrm{I} 28$ & Market access & Manager & 12 \\
\hline $\mathrm{I} 29$ & Marketing & Director & 13 \\
\hline $\mathrm{I} 30$ & Sales & Director & 11 \\
\hline $\mathrm{I} 31$ & Sales & Director & 22 \\
\hline $\mathrm{I} 32$ & Sales & Head of Region & 23 \\
\hline $\mathrm{I} 33$ & Sales & Head of Region & 23 \\
\hline I34 & Subsidiary & Director & 2 \\
\hline $\mathrm{I} 35$ & SCM & Director & 13 \\
\hline
\end{tabular}

